\title{
Determination of lead in guava (Psidium guajava) planted near Sagian Wala Bypass, Lahore
}

\author{
Amina Abrar*, Madiha Mushtaq, Moneeza Abbas and Rabia Shahzadi \\ Environmental Science Department, Lahore College for Women University, Lahore-Pakistan \\ *Corresponding author's email: amina.abrar@outlook.com \\ Citation \\ Amina Abrar, Madiha Mushtaq, Moneeza Abbas and Rabia Shahzadi.Determination of lead in guava (Psidium \\ guajava) planted near Sagian Wala Bypass, Lahore. Pure and Applied Biology. Vol. 6, Issue 1, pp256-260. \\ http://dx.doi.org/10.19045/bspab.2017.60021
}

Received: 05/10/2016

Revised: 07/02/2017

Accepted: 11/02/2017

Online First: 14/02/2017

\section{Abstract}

The present study deals with the determination of lead $(\mathrm{Pb})$ in Guava Planted along Sagian Wala Bypass, Lahore. Samples of guava were collected from different sites of Sigan Wala Bypass. The samples were subjected to wet digestion procedure. The concentrations of $\mathrm{Pb}$ in 20 composite samples were determined by using Atomic Absorption Spectrophotometer (AAS). The results of this survey showed that the average concentrations detected were ranged from 6.57 to 13.10 $\mathrm{mg} / \mathrm{kg}$. Concentration of $\mathrm{Pb}$ in all samples was found to be higher than the permissible limit approved by FAO/WHO $(0.3 \mathrm{mg} / \mathrm{Kg})$. The high content of $\mathrm{Pb}$ in Guava may pose a health hazard to consumers. The results indicate that there is considerable risk of lead poisoning from consumption of the guava from these sites.

Keywords: Heavy metals; Contaminants; Atomic absorption spectroscopy

\section{Introduction}

Agricultural areas near highways are usually subjected to air pollution by heavy metals including $\mathrm{Ni}, \mathrm{Pb}, \mathrm{Cr}, \mathrm{Zn}, \mathrm{Cu}$, and $\mathrm{Cd}$ etc. These metals are released from combustion of fuel from road transport, fluid leakage of metals and contaminated water. Most of these metals are toxic to living organisms and can pose health risk to humans [1]. Many plants have the tendency to assimilate metals from their surroundings and consumption of such plants, containing heavy metals at toxic concentrations, may cause a chronic health hazard to humans [2]. Vegetables and fruits are sources of metabolites; antioxidants and other essential nutrients and are the part of common diet taken by populations throughout the world
[3]. High concentration of these metals in fruits grown along road side is usually associated with toxicological problems. Heavy metals are hazardous because they tend to bioaccumulate. Consumption of the heavy metal contaminated fruits can lead to severe liver and kidney diseases. Heavy metal contamination of the food items is one of the most important aspects of food quality assurance [4]. Emissions of heavy metals from the industries and vehicles may be deposited on the vegetable surfaces during their production [5]. Therefore, there is the need to investigate the possible risks in the population due to the exposure of heavy metal contamination in vegetables and fruits Guava (Psidium guajava) is a small tree or an arborescent shrub. Its fruit is rich in 
minerals, fiber, vitamins $\mathrm{A}, \mathrm{C}$ and riboflavin as well as in proteins thus has a considerable nutritional importance [6]. Lead is nonessential heavy metals, because they have no nutritional importance for human body [7]. Lead may find the entry in guava cultivated along highways through air pollution from vehicular exhaust industrial activities in nearby vicinity [8]. Lead is highly toxic to humans with the injurious effects on the hemopoietic, nervous and reproductive system [9]. Objectives of the study was to determine the level of $\mathrm{Pb}$ in guava samples to evaluate the quality of guava fruit planted along Sagian Wala Bypass, Lahore.

\section{Materials and methods}

Samples of guava fruit were collected from different sites of Sigan Wala Bypass. Random sampling was done from four sites including road side, along river Ravi, near livestock farm, and near residential area.

Five composite Samples were prepared from each selected site. Each composite sample was prepared of four guava fruits from one tree. Fruits were washed with distilled water and cut into small pieces and mashed. Petri dishes containing mashed samples were kept in oven at $110-120^{\circ} \mathrm{C}$ for $2-3$ hours for drying. Dried samples were grinded into powder. Samples were weighed and placed in muffle furnace at $500-550{ }^{\circ} \mathrm{C}$ for $12-$ 18 hours. Organic matter was burnt and sample turn into ash. $1 \mathrm{~g}$ of ash from each sample was dissolved in $10 \mathrm{ml}$ of concentrated $\mathrm{HCl}$.

Samples were heated on controllable hot plate at $200^{\circ} \mathrm{C}$ for 30 minutes until the whole ash was dissolved. Samples were allowed to cool at room temperature and transferred to volumetric flask and diluted up to $50 \mathrm{ml}$ with distilled water. The samples were filtered with the help of Whatman filter paper and clear solution was obtained for Lead analysis. A standard solution of $\mathrm{Pb}$ of $1000 \mathrm{mg} / \mathrm{L}$ was diluted in to series of standard solution (2ppm, 4ppm, 6ppm) up to the mark with distilled water [10]. Lead analysis was done by the atomic absorption spectrophotometer for each prepared sample.

Results were tabulated and mean concentration of $\mathrm{Pb}$ in samples from each site, standard deviation and standard error of mean was obtained using SPSS statistical package. Results were compared with FAO/WHO permissible limit of $\mathrm{Pb}$ for fruits which is $0.3 \mathrm{mg} / \mathrm{kg}$ on a dry weight basis [11].

\section{Results and discussion}

The concentration of $\mathrm{Pb}$ in all Guava samples was ranged from 6.575 to 13.065 $\mathrm{mg} / \mathrm{kg}$. The $\mathrm{Pb}$ concentration was found to higher than the FAO-WHO maximum permissible limits in all the samples collected from the guava trees planted near Sigan Wala Bypass (Figure 1). Pb content in samples collected from site near livestock farms ranged from $6.575 \mathrm{mg} / \mathrm{Kg}$ to 8.2 $\mathrm{mg} / \mathrm{Kg}$. In the samples collected from the field near residential area the $\mathrm{Pb}$ content ranged from $8.18 \mathrm{mg} / \mathrm{Kg}$ to $8.815 \mathrm{mg} / \mathrm{Kg}$. highest concentration of $\mathrm{Pb}$ was found in samples collected from the field near River Ravi ranging from $11.085 \mathrm{mg} / \mathrm{Kg}$ to 13.065 $\mathrm{mg} / \mathrm{Kg}$. While samples collected along the road side showed the values of lead ranging from $9.22 \mathrm{mg} / \mathrm{Kg}$ to $9.96 \mathrm{mg} / \mathrm{Kg}$ as shown in Table 1. The mean concentrations of $\mathrm{Pb}$ \pm SEM $\mathrm{mg} / \mathrm{Kg}$ in Guava samples were found to be $7.464 \pm 0.34 \mathrm{mg} / \mathrm{Kg}, \quad 8.455 \pm 0.16$ $\mathrm{mg} / \mathrm{Kg}, 9.69 \pm 0.16 \mathrm{mg} / \mathrm{Kg}$ and $12.303 \pm 0.40$ $\mathrm{mg} / \mathrm{Kg}$ collected from fields near livestock farm, residential area, along road side and near river Ravi respectively (Figure 2). 


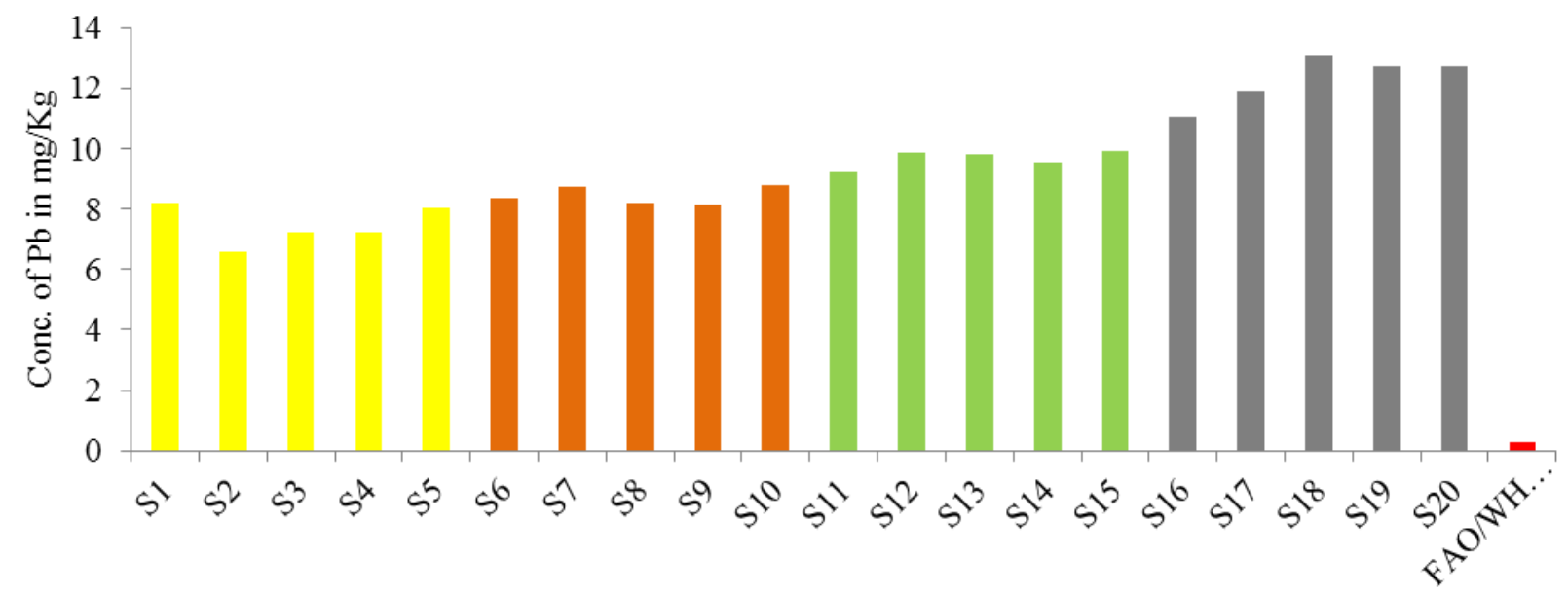

Figure 1. Showing the comparison of conc. of $\mathrm{Pb}$ in $\mathrm{mg} / \mathrm{kg}$ in samples collected from four selected sites with FAO/WHO Standard Limit

Table 1. Showing the mean concentration of $\mathrm{Pb}$ in $\mathrm{mg} / \mathrm{kg}$ in guava samples collected along Sagian Wala Bypass, Lahore

\begin{tabular}{|l|l|l|l|l|l|l|l|l|}
\hline Samples Sites & \multicolumn{3}{|l|}{$\begin{array}{l}\text { Conc. of Lead in mg/kg in 5 } \\
\text { composite samples from each site }\end{array}$} & $\begin{array}{l}\text { Mean conc. of } \\
\text { Pb in mg/kg }\end{array}$ & $\begin{array}{l}\text { Standard } \\
\text { Deviation }\end{array}$ & $\begin{array}{l}\text { Standard } \\
\text { Error Mean }\end{array}$ \\
\hline $\begin{array}{l}\text { Field near } \\
\text { Livestock farm }\end{array}$ & 8.2 & 6.57 & 7.25 & 7.22 & 8.06 & 7.46 & 0.67 & \pm 0.30 \\
\hline $\begin{array}{l}\text { Field near } \\
\text { Residential area }\end{array}$ & 8.36 & 8.75 & 8.18 & 8.16 & 8.81 & 8.45 & 0.31 & \pm 0.14 \\
\hline $\begin{array}{l}\text { Field along } \\
\text { Road side }\end{array}$ & 9.22 & 9.89 & 9.84 & 9.53 & 9.9 & 9.68 & 0.30 & \pm 0.13 \\
\hline $\begin{array}{l}\text { Field near } \\
\text { River Ravi }\end{array}$ & 11.08 & 11.9 & 13.1 & 12.74 & 12.72 & 12.31 & 0.82 & \pm 0.36 \\
\hline
\end{tabular}

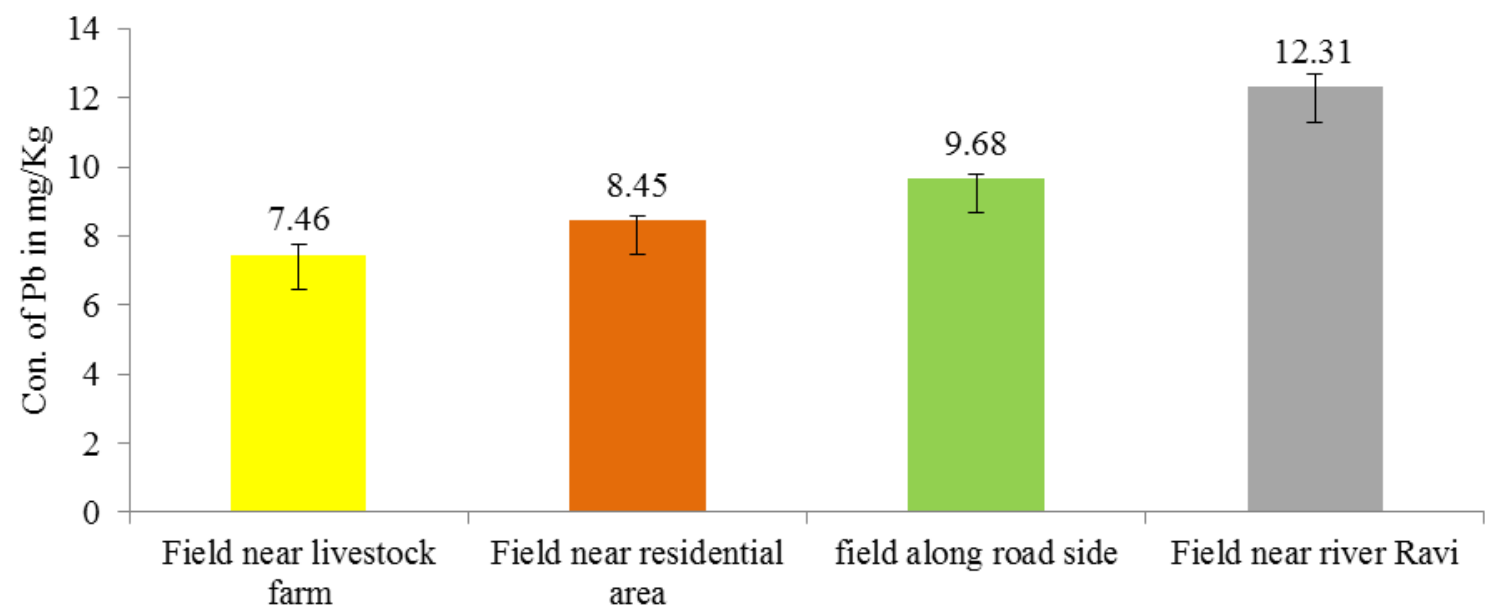

Figure 2. Showing the mean conc. of $\mathrm{Pb}$ in $\mathrm{mg} / \mathrm{kg}$ and $\pm \mathrm{SEM}$ in samples collected from four selected sites at Sagian Wala Bypass, Lahore 
The results also showed that samples collected from the field near river Ravi had highest $\mathrm{Pb}$ content than all other sites. These fields are irrigated with the water from River Ravi which receives wastewater containing heavy metals from multiple sources like industries, agricultural runoff and residential areas from in and around Lahore. The contamination of fruits might be closely related to the pollutants in the irrigation water. Wastewater irrigation is significant contributor to the heavy metal contents of soils. The present study is in agreement with the study conducted by Mapanda et al., 2005, which concluded that the use of wastewater for irrigation of soils in urban areas contain heavy metals to the concentrations posing health risk for human body [12].

Guava sample collected along roadside also showed higher values of $\mathrm{Pb}$ content. The high amount of $\mathrm{Pb}$ in these samples was due to vehicular pollution. High lead $(\mathrm{Pb})$ levels in urban areas are attributed to vehicular emissions and automobile exhaust mainly from lubrication oils and leaded gasoline. These sources can contaminate the fruits grown in areas near roads with high traffic load [13]. A research study was conducted to examine the intensity and effects of automobile related metal pollution on soil and physiological attributes of native plant species in India. Results of the study showed that lead and cadmium in soil were significantly higher in areas with high traffic volume [14].

Comparison with FAO/WHO permissible results shows that the samples for all four sites cross permissible limits and had higher concentrations of $\mathrm{Pb}$. Fruits containing high content of $\mathrm{Pb}$ may proves to be highly toxic to human body and affect nervous system, bones, liver, pancreases, teeth and gum. Consuming food containing high amount of $\mathrm{Pb}$ can also increase the risk of blood diseases [15].

\section{Conclusion}

The results obtained showed that high $\mathrm{Pb}$ content in samples collected from Guava planted along Sagian Wala Bypass, Lahore as compared to the FAO/WHO Standard Limit. This can pose a potential threat to the health of consumers. Because fruits are commonly used as essential part of our food and they are used in our daily life. It is concluded that the guava fruits grown in the area are a health hazard for human consumption.

\section{Authors' contributions}

Conceived and designed the experiments: A Abrar, Performed the experiments: M Mushtaq \& A Abrar, Analyzed the data: M Abbas, Contributed reagents/ materials/ analysis tools: R shahzadi. Wrote the paper: A Abrar.

\section{Reference}

1. Rahul J \& Jain MK (2016). Effect of Heavy Metals on Some Selected Roadside Plants and its Morphological Study. Nat Env Poll Tech 15(4): 1133 1142.

2. Giacomino A, Malandrino M, Colombo ML, Miaglia S, Maimone P, Blancato S \& Abollino O (2016). Metal content in dandelion (Taraxacum officinale) leaves: influence of vehicular traffic and safety upon consumption as food. $J$ Chem 2016: 1-9.

3. Khan ZI, Bibi Z, Ahmed K \& Asraf M (2014). Appraisal of Heavy Metal Concentrations in Edible Vegetable Abelmoschus esculentus (Lady Finger) Grown in Soil Irrigated with Domestic Sewage Water in Sargodha, Pakistan. Arab Gulf J Sci Res 32(3): 168-176.

4. Ali MH \& Al-Qahtani KM (2012). Assessment of some heavy metals in vegetables, cereals and fruits in Saudi Arabian markets. The Egyptian Journal of Aquatic Research 38(1): 31-37.

5. Afshin M \& Masoud AZ (2008). Heavy 
metals in selected edible vegetables and estimation of their daily intake in Sanandaj, Iran. Southeast Asian J Trop Med Public Health 39(2): 335-340.

6. Joseph B \& Priya M (2011). Review on nutritional, medicinal and pharmacological properties of guava (Psidium guajava Linn.). Int J Pharm Biol Sci 2(1): 53-69.

7. Ikem A \& Egiebor NO (2005). Assessment of Trace Elements in Canned Fishes marketed in Georgia and Alabama (United States of America). $J$ Food Comp Anal 18: 771- 787.

8. Jaishree TI (2016). Health risk assessment due to heavy metals in cow pea cultivated in Sanganer using textile waste water. IJSR 5(1): 791-796.

9. Muhammad F, Farooq A \& Umer R (2008). Appraisal of heavy metal contents in different vegetables grown in the vicinity of an industrial area. Pak J Bot 40(5): 2099-2106.

10. Duarte ÁT, Borges AR, Zmozinski AV, Dessuy MB, Welz B, de Andrade JB \& Vale MGR (2016). Determination of lead in biomass and products of the pyrolysis process by direct solid or liquid sample analysis using HR-CS
GF AAS. Talanta 146: 166-174.

11. FAO/WHO (2004). Fruit and vegetables for health. Kobe, Japan: Report of Joint FAO/WHO Workshop. Kobe, Japan.

12. Mapanda F, Mangwayana EN, Nyamangara J \& Giller KE (2005). The effect of long term irrigation using wastewater or heavy metal content of soils under vegetables in Harare, Zimbabwe. Agric Ecosyst Environ 107: 151-165.

13. Shamyla N, Mumtaz H, Muhammad A, Muhammad YA \& Amer J (2012). Effect of Automobile Related Metal Pollution $(\mathrm{Pb} 2+\& \mathrm{Cd} 2+)$ on some Physiological Attributes of Wild Plants. Int J Agric Biol 14(6): 953-958.

14. Kumar R, Agrawal $M$ \& Marshall $F$ (2007). Heavy metal contamination of soil and vegetables in suburban areas of Varanasi, India. Ecotoxicol Environ Saf 66(2): 258-66.

15. Igwegbe AO, Agukwe $\mathrm{CH} \&$ Negbenebor CA (2013). A survey of heavy metal (lead, cadmium and copper) contents of selected fruit and vegetable crops from Borno State of Nigeria. Int $J$ Eng Sci 2(1): 1-5. 